\title{
Daniele Tripaldi
}

\section{Edfu and the Oriens: On Re-discovering Ancient Egyptian Lore in Two Coptic Apocalypses}

DOI 10.1515/zac-2016-0007

\begin{abstract}
The article attempts to examine anew two classical cases of alleged continuity of ancient Egyptian traditions into Coptic Late Antique and its literature. Formal correspondences are sought, possible channels of transmission are surveyed and discussed, the explanatory potential of the identified survivals is ascertained. A few concluding remarks on detecting and reconstructing transfers of knowledge in and through literary texts are finally added.
\end{abstract}

Keywords: Coptic Apocalypses, Ancient Egyptian Worldview, Transfer of Knowledge

In a paper presented in Naples last September, entitled "Late Antique Alexandria and the Oriens," Mark Edwards correctly pointed out that we should apply three main criteria for identifying influences of Oriental wisdom, in his case Egyptian and Indian, on Plotinus: first of all, a solid lexical and conceptual basis for comparison is to be sought and found; second, we need to be able to establish channels by which the tradition under focus reached the author or the text we are studying; third, the more explanatory potential the reconstructed influence or allusion deploys in our understanding of a passage, the more it gains in historical probability. ${ }^{1}$

As I owe Edwards the first part of the title of my contribution, I shall make an attempt to extend the range and explore the full critical potentials of his criteria as well. I shall put under scrutiny some passages excerpted from two Late Antique Coptic "revelations" and search them for survivals of ancient Egyptian lore. The selected texts are The Mysteries of John, Apostle and Virgin and an Encomium

1 Mark Edwards, "Late Antique Alexandria and the Oriens," forthcoming in Beyond Conflicts: Cultural and Religious Cohabitations in Alexandria and Egypt between the 1st and the 6th cent. C. E. (ed. Luca Arcari). Cf. already the methodological premise in Aldo Magris, "Plotino e l'India," Annuario Filosofico 6 (1990): (105-162) 105-107, currently in reprint.

Daniele Tripaldi: Alma Mater Studiorum - Università di Bologna, Dipartimento di Filologia Classica e Italianistica, Via Zamboni 32, 40126 Bologna, Italy, e-mail: daniele.tripaldi@unibo.it 
of John the Baptist attributed to John Chrysostom, also known as The Glory of the Precursor, after the words of praise which open the text. These two works are transmitted by two distinct manuscripts coming from the Monastery of St. Mercury at Edfu, now in the British Museum (London, British Museum Oriental [BM Or.] 7026 and 7024), and dating respectively to 1006 and 985 C. E. ${ }^{2}$ The texts themselves are probably at least two century older than the codices, The Mysteries of John going back to the 7th-8th century, The Glory of the Precursor to the 8th, and certainly no earlier than the 6 th. ${ }^{3}$

\section{On the Inundation and Primordial Waters ${ }^{4}$}

The Mysteries of John opens by setting the stage of a vision of the resurrected Jesus on the Mount of Olives. There, the Savior sits down and gathers the twelve apostles already scattered all over the earth to preach the Gospel. John takes the lead and begs Jesus to show him the mysteries of heaven. After a brief prayer is said, his wish is fulfilled: taken up into heaven on the wings of a Cherub, John first sees twelve men sitting on twelve thrones. Asked who they are, the angel explains they are the princes of the worlds of light, each one regulating the course of one year under Michael's supervision, in order to grant humans a good harvest. John's curiosity then turns abruptly to the rising and abating of the Nile's waters.

Let me quote the whole passage (BM Or. 7026, f. 3r-4r) from the German translation I am currently working on for the Antike christliche Apokryphen:

2 See Ernest A. Wallis Budge, Coptic Apocrypha in the Dialect of Upper Egypt (Apocrypha testamenti novi; New York: AMS, 1913), xxii-xxiv and 1-lii, and Tito Orlandi, "Les manuscrits coptes de Dublin, du British Museum et de Vienne,” Le Muséon 89 (1976): (323-338) 330. As sources for the reconstruction of the text of the Glory of the Precursor, Anne Boud'hors, "Éloge de JeanBaptiste," in Écrits apocryphes chrétiens 1 (ed. François Bovon and Pierre Geoltrain; Bibliothèque de la Pléiade 442; Paris: Gallimard, 1997), (1553-1578) 1558, mentions also a much later and still unedited Arabic version transmitted by three manuscripts, and three more Coptic fragments on parchment (10th century C. E.), once part of the library of the White Monastery near modern Sohag, now in the Bibliothèque Nationale de France. However, despite the presence of similar passages, it is unsure whether the latter actually come from the same work preserved in BM Or. 7024.

3 I am greatly indebted to Paola Buzi (Sapienza-Università di Roma) who helped me decisively in dating the two works. To her goes my sincere gratitude. On the date of The Glory of the Precursor, Boud'hors, "Éloge de Jean-Baptiste" (see note 2), 1557, wrote: "La composition assez confuse du texte amène à supposer que l'auteur a pu fondre dans une version copte des éléments narratifs et exégétiques de provenances diverses, connus de lui en grec ou en copte. Cette version n'est probablement pas antérieure à la fin du VIe siècle.”

4 See Budge, Coptic Apocrypha (see note 2), lxvii-lxviii. 
Da antwortete ich dem Cherubin: "Mein Herr, ein Jahr kommt, in dem das Überschwemmungswasser sinkt, und trotzdem tritt die Fülle ein; es kommt aber ein Jahr, in dem die Überschwemmung schwillt, und trotzdem tritt Hungersnot ein.” Er antwortete mir und sagte: "Du hast das Wasser gesehen, indem es unter den Füßen des Vaters lag: wenn er seine Füße hebt, schwillt das Wasser. Wenn Gott dabei ist, das Wasser herbeizubringen, falls die Menschen sündigen, dann verringert sich die Frucht des Wassers wegen der Sünden der Menschen; wenn aber Gott nur ein wenig Wasser schwellen (Coptic: mouh, "to fill”) lässt (f. 3v), falls die Menschen sich vom Sündigen fernhalten, dann segnet es der Vater und es vermehren sich seine Früchte dank Michaels Gebeten. Würden die Menschen von Michaels Gebeten zur Zeit des Kommens des Wassers auf die Erde erfahren, würden sie gar nicht sündigen. Denn Michael nimmt zwölfhunderttausend Engel mit sich und alle zusammen treten zu dem Vater ein, werfen sich nieder vor seinem Angesicht, und stehen nicht mehr auf, bis Gott das Wasser auf die Welt sendet.” Ich nahm das Wort und sagte zu dem Cherubin: "Ich habe davon gehört, dass im Anfang Gott Erde und Himmel schuf, so wie auch das Wasser selbst.” Da sagte (f. 4r) der Cherubin zu mir: "Hör mir zu und ich werde dich über alles belehren! Bevor Gott Erde und Himmel schuf, waren die Gewässer schon da und niemand weiß wie sie erschaffen wurden, außer Gott allein."

Two basic concepts lie at the core of this passage: 1 . the waters of the Nile are under God's feet: they come and go at his will, and the latter might be influenced by Michael's intercession; 2 . the waters of the Nile preexist the beginnings of creation as God alone existed together with them and knows how they came into being. ${ }^{6}$

The roots of both ideas can easily be traced back to ancient Egyptian traditions. I list here some parallels not recorded by E. A. Wallis Budge, almost all of

5 Mysteria Iohannis 4 (BM Or. 7026, f. 3r-4r; ed. Budge, Coptic Apocrypha [see note 2], 60-61):

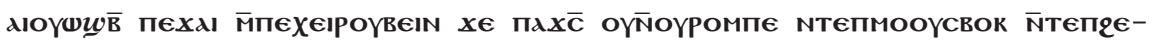

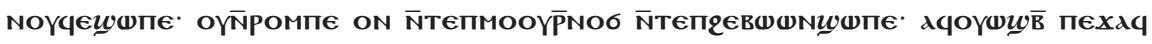

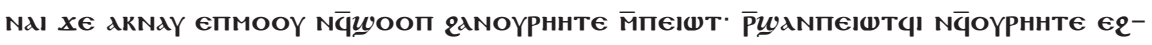

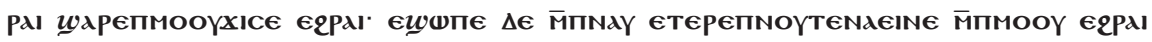

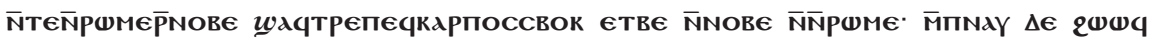

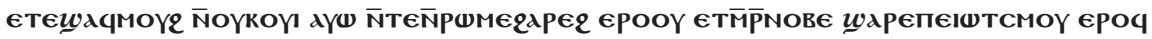

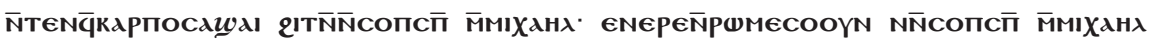

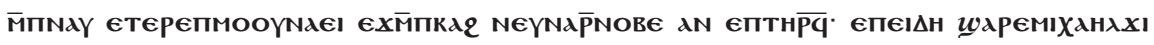

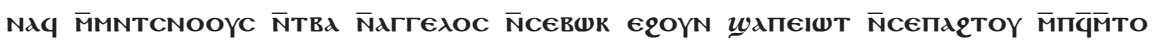

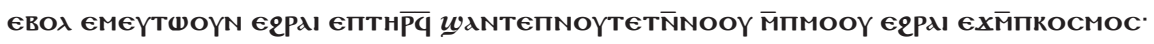

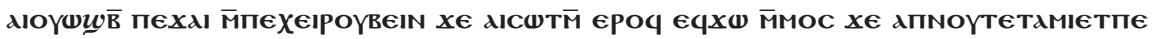

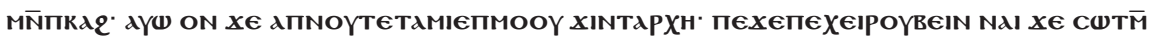

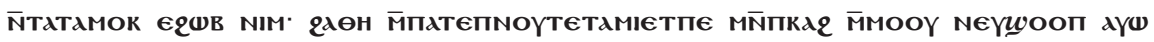

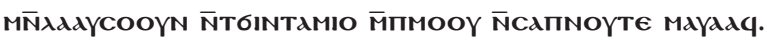

6 On Late Antique and Byzantine views of the Nile's inundation as re-enactment of the beginnings of creation, at the crossroads of Egyptian, Greek, Jewish, and Christian traditions, see Danielle Bonneau, La crue du Nil: divinité égyptienne à travers mille ans d'histoire, 332 av. - 641 ap. J. C.: d'après les auteurs grecs et latins, et les documents des époques ptolémaique, romaine et byzantine (Études et commentaires 52; Klincksieck: Paris, 1964), 423-424. 
them from inscriptions dating to the Persian and Graeco-Roman period (except for the first): ${ }^{7}$

To 1.: ÄHG 141,3-4 (Ramesside period; of Amun as cosmic and creator God): 8 "Er dringt in die (tiefsten) Grüfte unter seinen Füßen, der Nil kommt aus der (innersten) Höhle unter seinen Sohlen.” ÄHG 129,59-61 (kingdom of Darius I; of Amun as cosmic and creator God): ${ }^{9}$ "er hat Rat gepflogen mit seinem Herzen, als er dies alles plante, er hat Himmel und Erde entworfen in ihrer Eigenart, als er die Entstehung der Höhlungen ersann unter seinem Thron.” ÄHG 129,141-142: "Der Nilbringer, er hat die Quellöcher aufgebrochen, er hat das Wasser strömen lassen aus seiner Höhle, es schwillt und sinkt nach seinem Belieben.” Later sources mention both caves and grotto without further specifying their actual position-presupposing then probably their traditional location under the god's feet or throne: ${ }^{11} U r k$. VIII 8b, 70b, 57b (Ptolemaic period; of Amun as cosmic and creator God): ${ }^{12}$ "Air goes out for him, light comes forth for him, the Inundation pours out for him from its grotto (tpht.f)." Different gods may be requesting, satisfying, pacifying Amun-Kematef in his name of Nun the Elder residing in

7 Cf. the similar methodological shift now occurring in the study of the Egyptian roots of Hermetism as stressed by Alberto Camplani, Jørgen Podemann Sørensen, and Sissel Undheim, review of Christian Bull, The Tradition of Hermes: The Egyptian Priestly Figure as a Teacher of Hellenized Wisdom (PhD diss.), Adamantius 20 (2014): (490-493) 490: “In the Twentieth century Egyptian elements were identified on the base of conceptual parallels between Hermetic writings and Egyptian texts of all historical periods, with preference for the most ancient ones. Nowadays it is increasingly becoming mandatory to find Egyptian aspects of Hermetism by comparing Hermetic writings with late Egyptian texts written under Greek or Roman rule, whatever the degree of Egyptianism or Hellenism detectable in them.”

8 Ägyptische Hymnen und Gebete 141,3-4 (ed. Jan Zandee, Hymnen aan Amon van Pap. Leiden I 350 [Leiden: Brill, 1947], 99; trans. Jan Assmann, Ägyptische Hymnen und Gebete [2d ed.; Freiburg/Schweiz: Universitätsverlag, 1999], 335; hereafter abbreviated as $\ddot{A} H G$ and cited with number and line).

$9 \ddot{A H G}$ 129,59-61 (ed. David Klotz, Adoration of the Ram: Five Hymns to Amun-Re from Hibis Temple [Yale Egyptological Studies 6; New Haven, Conn.: Yale Egyptological Seminar, 2006], 148,12-14; trans. 306 A.).

$10 \ddot{A} H G$ 129,141-142 (161,28 K.; trans. 306 A.).

11 On the cluster of ideas revolving around the divine throne as primeval mound, sanctuary, and divine burial place, and qua primeval mound and divine crypt as grotto and source of Nun waters inundating the land, see David Klotz, Adoration of the Ram (see note 9), 23, 102-103, 116-122, and idem, Caesar in the City of Amun: Egyptian Temple Construction and Theology in Roman Thebes (Monographies Reine Élisabeth 15; Turnhout: Brepols, 2012), 140-141, 181-183. On heavens, the Two Lands, and river mouths lying under thrones, cf. Klotz, Adoration of the Ram (see note 9), 43 (with note 244), 111, 114-115, 148, 157. Alfred Hermann, “Der Nil und die Christen,” JbAC 2 (1959): (30-69) 47 (note 116), refers to the Egyptian technique, current from Ptolemaic times onwards, of providing temples with running river water by means of underground pipes.

12 Urkunden des ägyptischen Altertums VIII 8b; 70b; 57b (ed. Kurt Sethe, Urkunden des ägyptischen Altertums 8: Thebanische Tempelinschriften aus griechisch-römischer Zeit [Berlin: Akademie Verlag, 1957], 7; 58; 46; trans. Klotz, Caesar in the City of Amun [see note 11], 63 [with note 132]); hereafter abbreviated as Urk. and cited with volume and number, followed by the page in parentheses. 
his grotto and retaining control over the Inundation, in order that he might send Nun-waters on earth: see for example Urk. VIII 90c (75; Ra), 36c.f (31; Amenope of Djeme), 119 [6] (96; Chonsu-Shu) and a bandeau inscription from the bark shrine at Medinet Habu (Ra again).

To 2.: Deir Chelouit II 76,15: $:^{13}$ Amun as the one "who was born in the inception in Nun, who arose in the beginning before the earth was created"; $P M \mathrm{II}^{2} 466,38 \mathrm{a}:{ }^{14}$ Amun is called "he who created Nun, and he who arose within it while the land was mixed with darkness"; Urk. VIII 79h: "when the august Ba emerged from Nun, while earth was filled with darkness ... he lifted up the sky and set down the earth"; ${ }^{15}$ Urk. VIII 84h: "when the hidden Ba showed his head in Nun, being alone, with nobody else except himself, . . . the ground upon his sides, wind and waters emerging from his coils / innards." ${ }^{16}$

So far, in this case, Egyptian literary evidence does enable us to identify ideas and worldview and to follow their transmission and developments through centuries in written tradition. The Nile floodcults, however, did not exhaust themselves in written tradition, texts and temple inscriptions.

Having assured a continuously transmitted and reworked lexical and conceptual cluster to build upon, we come to the second point stressed by Edwards, that is, the need to detect and specify the historical channels of transmission. We know that songs and hymns to the Nile were composed for and performed during rites until the 6th century C. E. ${ }^{17}$ As David Frankfurter writes, "Nile rites consisted in their most basic form of the procession of a local god's bark shrine

13 Deir Chelouit II 76,15 (ed. Christiane Zivie-Coche, Le Temple de Deir Chelouit: Les inscriptions 2 [Cairo: Publications de l'Institut Français d'Archéologie Orientale, 1983], 76,15; trans. Klotz, Caesar in the City of Amun [see note 11], 59); hereafter abbreviated Deir Chelouit II and cited with page and line.

$14 \mathrm{PM} \mathrm{II}^{2}$ 466,38a (ed. Bertha Porter and Rosalind L. B. Moss, Topographical Bibliography of Ancient Egyptian Hieroglyphic Texts, Reliefs, and Paintings 2: Theban Temples [2d ed.; Oxford: Clarendon Press, 1972], 466,38a; trans. Klotz, Caesar in the City of Amun [see note 11], 135); hereafter abbreviated PM II ${ }^{2}$ and cited with page and line.

15 Urk. VIII 79h (66; trans. 135-136 [with note 777] K.).

16 Urk. VIII 84h (70; trans. $135 \mathrm{~K}$.$) .$

17 Cf. Aeschylus, Supplices 1024-1025 (SCBO Aeschyli septem quae supersunt tragoedias, 131 Page); Parmeno of Byzantium 604A (ed. Hugh Lloyd-Jones and Heinz-G. Nesselrath, Supplementum Hellenisticum [Texte und Kommentare 1; Berlin: de Gruyter, 1983], 288,1; 3d century

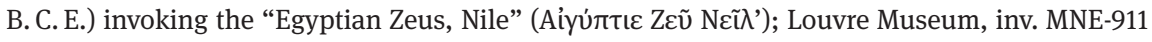
(ed. Raffaella Cribiore, "A Hymn to the Nile," Zeitschrift für Papyrologie und Epigraphie 106 [1995]: [97-106] 98,3; 3d-4th century C. E.) calling upon the Nile as "one of the sacred waters of encircling Ocean"; Aristainetos according to Pseudo-Nonnus, Scholia ad Invectivam secundam 27 (ed. Sebastian Brock, The Syriac Version of the Pseudo-Nonnos Mythological Scholia [University of Cambridge Oriental Publications 20; Cambridge: Cambridge University Press, 1971], 145-146; 6th century C. E.) refers to antiphonal hymns sung in honor of the Nile, praising it for performing the work of Zeus and watering the country. See also David Frankfurter, Religion in Roman Egypt: Assimilation and Resistance (Princeton: Princeton University Press, 1998), 42-46. 
to the river's bank in order that the god might convince the river to bring an abundant inundation." 18 Therefore, ideas on the sources of the inundation, their position with respect to the god in charge over them, the pre-existence of the water may have been common knowledge to be learnt in the due course of ritual praxis, rather than merely written lore accessible to a limited circle of religious specialists as we now have them.

By Roman times, the flooding had long fallen under the supervision and command of Sarapis as Graeco-Egyptian cosmic god. ${ }^{19}$ The Christian turn apparently came under Michael's name around 325 C.E. ${ }^{20}$ As Socrates reports, ${ }^{21}$ Constantine the Great had the cubit in use for measuring the rising waters moved from Sarapis' temple to the church of the Alexandrians. According to a fragmentary Coptic manuscript preserved at the Institut Français d'Archéologie Orientale and identified by Tito Orlandi, this church of the Alexandrians is none other than the church dedicated to the archangel Michael. ${ }^{22}$

Later Coptic literature does prove the long and almost obvious persistence of interest in the theological economy of the flood of the Nile, as well as the commonality of language and themes in texts dealing with it. ${ }^{23}$ I cite just a few examples.

Even though the text gives no name to the majestic angel presiding over the inundation, the Apocalypse of Shenoute shares the same concern about waters rising short of human and animal needs, as well as the motif of angels supplicating its increase:

18 Frankfurter, Religion in Roman Egypt (see note 17), 44 (with note 18). Frankfurter collects Vita Pachomii bohairica 4; Papyrus Oxyrinchus 43, 3148 (424 C. E.); Papyrus Londinium literarius 239; Inscriptio Graeca Akoris 41; Inscriptio Graeca Philae 187 as additional evidence for the "resilience of the traditional Nile cult" (ibid., 44). On the survival of ritual baths in the Nile, practiced both by Christians and Muslims at least until the 11th century, and the older cultural beliefs underlying it, see Hermann, "Der Nil und die Christen" (see note 11), 47-50. Cf. Historia monachorum in Aegypto 8,25 (ed. André-J. Festugière, Historia monachorum in Aegypto [Subsidia hagiographica 53; Brussels: Société des Bollandistes, 1971], 56,161-165), relating about 4th century C. E. Hermopolis. 19 Cf. Aelius Aristides, In Serapidem 56,1-7 (ed. Wilhelm Dindorf, Aristides 1 [Leipzig: Weidmann, 1829; repr., Hildesheim: Olms, 1964], 96,20-97,4). Rufinus, Historia ecclesiastica 11,30 (GCS 9,2, 1035,15-1036,2 Mommsen). See Hermann, “Der Nil und die Christen” (see note 11), 33. See also Reinhold Merkelbach, Isis Regina-Zeus Sarapis: Die griechisch-ägyptische Religion nach den Quellen dargestellt (Stuttgart: Teubner, 1995), 74-75, 77-81 for more evidence.

20 Hermann, "Der Nil und die Christen" (see note 11), 33, 44-46.

21 Socrates Scholasticus, Historia ecclesiastica 1,18,2-3 (SC 477, 182,4-12 Périchon/Maraval).

22 Oral communication by Paola Buzi. The fragment has not been published yet. On the identification of the church, cf. already Bonneau, La crue du Nil (see note 6), 429-430.

23 For continuities and changes in Christian ritual praxis intended to assure the rise of the Nile, see Bonneau, La crue du Nil (see note 6), 434-435, 438. 
What I saw in the month of Epep: I saw water under the firmament, and there were people on earth mourning and grieving, because they longed to drink from that water. I saw a man standing on it, who shone like the sun and didn't want to give it to them to drink. Many times that vision was shown to me: the people on earth supplicating, the one on the waters of rivers holding them back. Many times I saw the regulations of the water, but never did I see it like that this time. When we approached the month of Mesore, I saw that man letting waters fall little by little. Thereafter, I saw a big scorching exhalation coming right after the water: it fell down on men and cattle. I asked them: "What is this fire?" They told me: "It's plague and death." Some people came to me in those days because of their cattle: "Maybe they have been bewitched!" I said: "No! Rather, it is God's hand!" I wondered about the vision: "Who are those mourning and asking for the water?" The one who was instructing me on these matters said: "They are the angels ruling over the earth. The one shining like the sun is the angel of the water of rivers. For no creature exists without God's providence; rather, by God's decree, the whole world is run by angels." 24

The Trishagion transmitted by the manuscript Vienna, Österreichische Nationalbibliothek K9740, also refers to anonymous angelic hosts praying to God for waters to increase and adds mention of the fruits of the year to be blessed (lines 14-23):

HoLY GoD: the archangelic powers and the chorus of the saints make supplication to thee, o lover of man. Holy AND Mighty: thou wilt not put the human race to death, nor make the city a desert, $\mathrm{O}$ just and good one. Holy AND Immortal: make, we beseech thee, the waters of the river to rise; bless, we beseech thee, the fruits of the year; for we expect them all for our nourishment. ${ }^{25}$

24 Apocalypsis Sinuthii 1 (CSCO 73, 198,15-199,16 Leipoldt/Crum): пеı̨шв NTaıNaY epoq 2M-

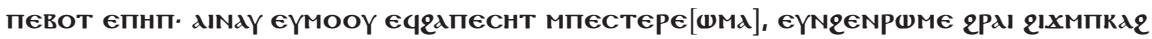

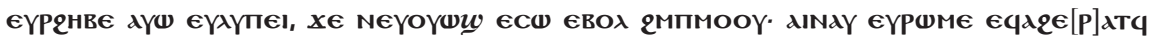

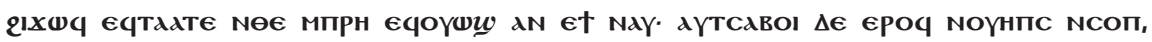

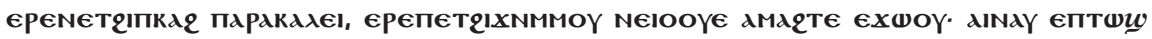

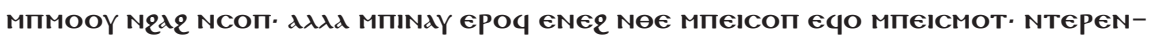

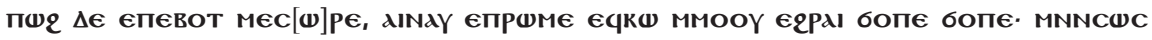

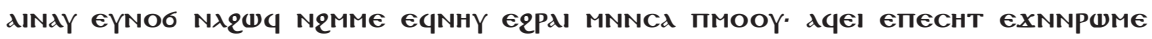

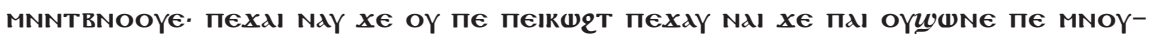

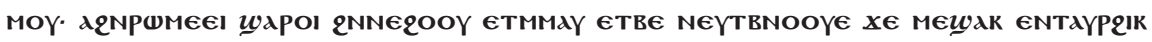

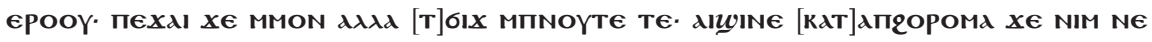

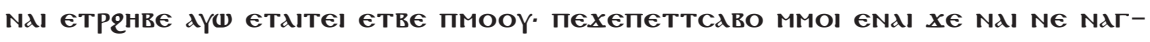

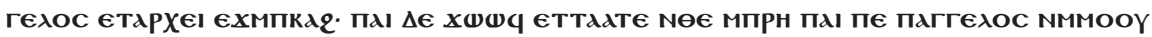

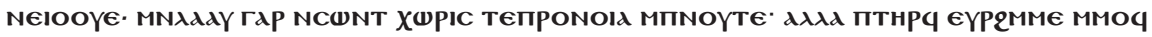

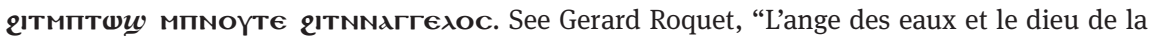
crue selon Chenoute. Sur un fragment copte des visions de l'Apocalypsis Sinuthii," Apocrypha 4 (1993): 83-99.

25 Gebet bei der Nilschwelle 14-23 (ed. Carl Wessely, Griechische und koptische Texte theologischen Inhalts 4 [Studien zur Paläographie und Papyruskunde 15; Leipzig: Haessels, 1914], 153; trans. Leslie S. B. MacCoull, "Stud. Pal. XV 250ab: a Monophysite Trishagion for the Nile Flood,"

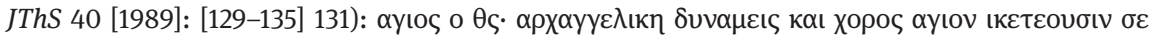


The importance of Michael's intercession for an abundant flood and rich harvest, as well as the ecological impact human sin may have on the Nile, dew, rain, and crops, find further echo in two homilies attributed to Athanasius and transmitted by a 9th century codex, from the monastery of Hamuli, now at the Pierpont Morgan Library in New York. ${ }^{26}$ On its part, a 10th century Coptic hymn to the archangel Michael originating from Upper Egypt mentions Michael's prayers to God, the rising of the waters, and the growth of the fruit of the land all at once:

Freut euch heute, ihr Engelchöre. Denn Gott hat das Flehen derer erhört, die zu ihm rufen. Durch die Bitten Michaels, des heiligen Engels, hat er sein Erbarmen und seine Macht gesandt und uns errettet. Die Wasser (des Nils) sind geschwollen. Die Frucht ist gewachsen. Und die, welche über uns gekommen waren, haben sich vor uns erniedrigt. ${ }^{27}$

All in all, judging from this brief review, the motif of the waters running under God's feet and preexisting creation seems more marginal and isolated than the other themes accompanying it in The Mysteries of John. ${ }^{28}$ Nonetheless, one might speculate that it was probably equally at home in the social and literary world of ritual praxis and expertise as its Sitz im Leben-or perhaps better: im Fortleben. My second test-case leads me on to far less safe ground.

\section{Traversing Eternity?}

In The Glory of the Precursor, the fictive author of the encomium, playing the role of John Chrysostom, relates how he, while staying in Jerusalem, came across a

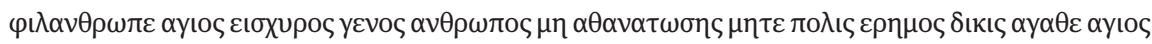

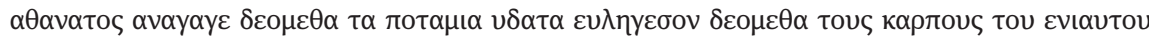

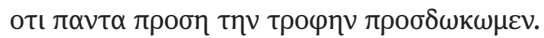

26 Ps.-Athanasius, Homiliae copticae (New York, Pierpont Morgan Library M 602, f. 219-220 and f. 143-144; trans. Tito Orlandi, Omelie Copte [Corona Patrum 7; Torino: SEI, 1981], 70, 88).

27 Von dem Erzengel Michael (ed. Hermann Junker, Koptische Poesie des 10. Jahrhunderts 2 [Berlin: Curtius, 1911], 194; trans. Hermann, "Der Nil und die Christen" [see note 11], 44-45): Xalp€

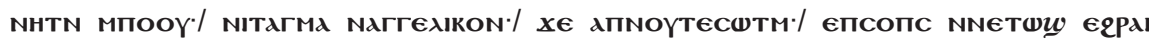

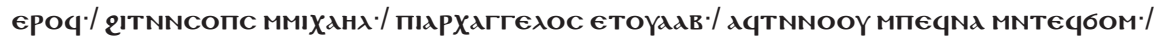

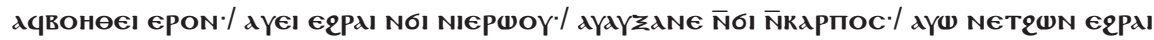
єхшN/ аүөввіо мпєемто євод.

28 For further formulas in our text centering on the Nile flood, and paralleled in Coptic liturgies, see Eusèbe Renaudot, Liturgiarum Orientalium Collectio 1 (Frankfurt: Baer, 1847; repr., Farnborough: Gregg, 1970), 8 (blessing the waters) and 16 (blessing and filling the waters). Instances of lexical and thematic recursivity in Nile liturgies transmitted in Greek and Syriac are collected by Bonneau, La crue du Nil (see note 6), 438. 
little book written by the Apostles themselves (BM Or. 7024, f. 9v-10r). The book reported a vision of theirs which took place on the Mount of Olives: the resurrected Jesus appeared to them, and, after commanding them to spread the Gospel in the whole world, turned to speak of John and the honors which he had granted him in the afterlife. As the Apostles ask him for further explanation, Jesus makes a luminous cloud descend and leads them into a first tour of the seven heavens (10r-11r). As it ends, Jesus brings them all back to the third heaven and gathers Apostles and angels around John the Baptist and his family (11r-12r). Taking then the role of the encomiast, Jesus spins his own encomium of John, and lists the privileges the latter enjoys in the hereafter (12v-14r; 15v-16r):

"Ich sage dir, mein geliebter Johannes, der du würdig warst, mich mit deinen heiligen Händen zu taufen: wenn irgendeiner in deinem Namen Primizien an deinem Ort aufteilt, oder einen Hungrigen speist, oder einen Durstigen tränkt, oder einen Nackten kleidet, solche werde ich vom Amente für immer und ewig nichts erfahren lassen, sondern du wirst sie ins ewige Leben hinein nehmen, und ich werde sie von meinen Engeln mit deren Lichtflügeln überdecken lassen. Ihnen werde ich die Güter geben, die sich in meinem Königreich befinden.” (f. 13r) ... “Jedermann, der sich deiner auf der Erde erinnern wird-wahrlich sage ich dir, mein Verwandter, Johannes-, den werde ich vom Amente und seinen Strafen für immer und ewig nichts erfahren lassen, auch noch am Feuerfluss, den jeder zu durchqueren haben wird, sei es ein Gerechter oder ein Sünder. Siehe, noch diese Gabe gewähre ich dir: diejenigen, die sich deiner auf der Erde erinnert haben werden, wirst du im Fährschiff des Feuerflusses, dem goldenen Schiff, über den Feuerfluss überfahren.” Wir, die Apostel, fragten ihn: "Herr, wie viele Stadien reicht der See des (f. 13v) Feuerflusses? Belehre uns, damit wir die Menschen lehren, sich vor ihm zu fürchten!” Da antwortete uns der Erlöser: "Ich werde euch über dessen Breite, sowie über das Ausmaß des goldenen Schiffes belehren, dasjenige Schiff, das ich meinem lieben Johannes gegeben habe. 30 Wellen reicht der See des Feuerflusses, von Ufer zu Ufer, und 30 Stadien jede Welle, von Kamm zu Kamm. Ich gewähre aber das goldene Schiff dem Johannes, meinem Verwandten, zum Überqueren des Feuerflusses, damit er darin diejenigen übersetze, die sich seiner auf der Erde erinnert haben werden, sei es mit einem kleinen Stück Brot oder einem Schluck kalten Wassers gewesen. Wenn sie zu der letzten Welle gelangen, taufe ich sie im Feuerfluss: wenn es dazu kommt, jeden zu taufen, der sich an Johannes erinnert, wird der Feuerfluss für sie wie Badewasser, und zwar warmes Wasser, sein-außer nur an dem Ort, an dem man baden wird im Feuerstrom. ${ }^{29}$ (f. 14r) Deswegen, mein Gefährte und Verwandter, Johannes, befehle ich dir, jeden,

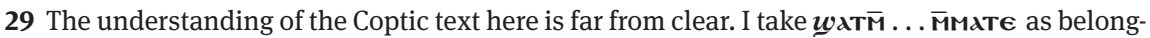
ing together (see Walter E. Crum, A Coptic Dictionary [Oxford: Clarendon Press, 1939; reprint, 1962], 593b, quoting Emile Amélineau, Oeuvres de Shenoudi: texte copte et traduction française 2,1 [Paris: Leroux, 1911], 349,2). Other translations of this prepositional syntagm plus relative have been proposed: "in the place wherein he washeth himself; even so shall the river of life (sic!) be” (Budge, Coptic Apocrypha [see note 2], 347); “mais l'endroit où l'on se baigne, c'est bien la rivière de feu" (Boud'hors, "Éloge de Jean-Baptiste” [see note 2], 1574); "bis (= auch noch an -) zu dem Ort, wo der Mensch im Feuerstrom baden wird" (Walter C. Till, "Johannes der Täufer in 
der sich deiner auf der Erde erinnern wird, sei es mit einem Opfer, oder Primizien, oder irgendwelcher, an deinem Ort zur Erinnerung deines heiligen Namens aufgeteilten Gabe, über den Feuerfluss in dem goldenen Schiff zu überfahren, das ich dir gewährt habe, und sie in den dritten Himmel hineinzunehmen, damit sie die ewig bestehenden Güter genießen, die da für sie bereit sind." ${ }^{30}$

There follows a long vision of the third heaven, depicted as a new fragrant and overabundant garden of Eden, whose vineyards, palm-trees, fig-trees, and appletrees produce enormous quantities of huge-sized fruits.

(f. 15v) Da sagte Petrus nochmal zum Erlöser: "Unser Herr und unser Gott, beschreibe uns diese Ruder und diese Lampen!” Da antwortete (f. 16r) der Erlöser: “Jedes Ruder eine Lampe, jede Lampe sieben Dochtlöcher, ausgefüllt und leuchtend. Jeder, der am Ort des heiligen Johannes, oder auch nur vor seinem Bild, die Lampe anzünden wird, der wird über den Feuerfluss in dem goldenen Schiff überfahren werden, das ich meinem lieben Johannes gegeben habe, und diese Leuchter werden vor ihrem Angesicht brennen, und sie beleuchten,

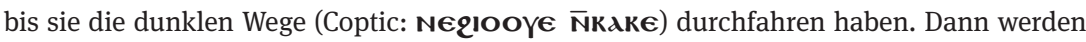

der koptischen Literatur,” Mitteilungen des deutschen archäologischen Instituts: Abteilung Kairo 16 [1958]: [310-332] 330).

30 Gloria Praecursoris 6-7 (BM Or. 7024, f. 12v-14r, ed. Budge, Coptic Apocrypha [see note 2],

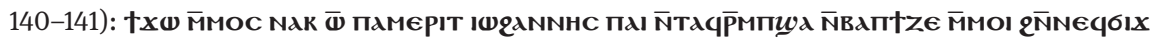

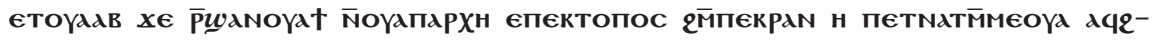

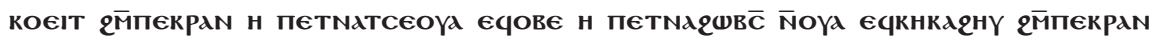

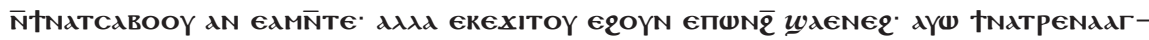

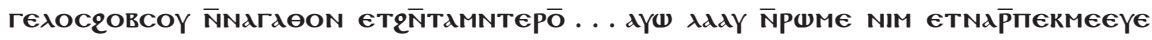

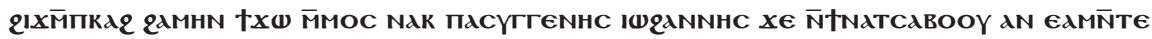

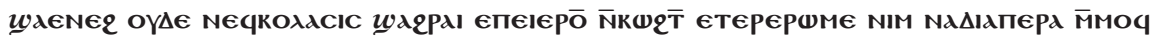

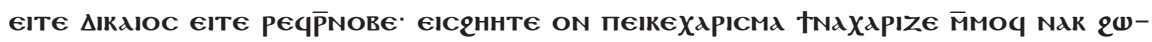

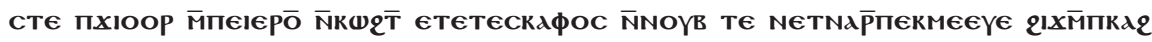

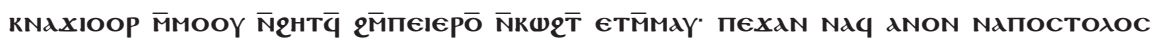

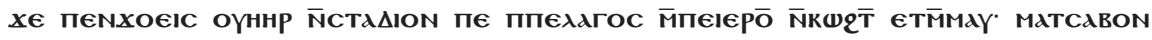

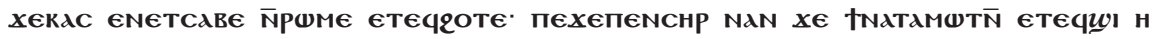

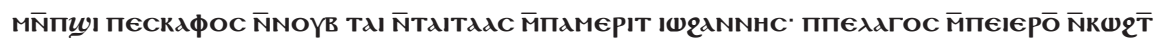

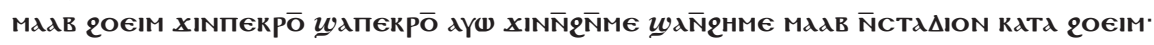

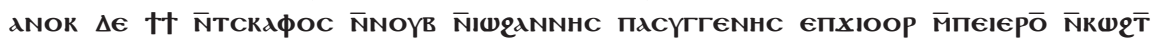

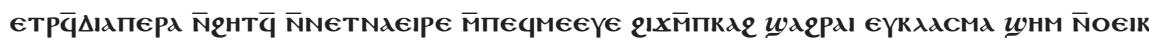

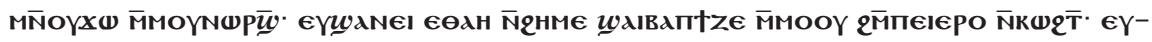

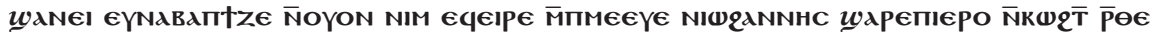

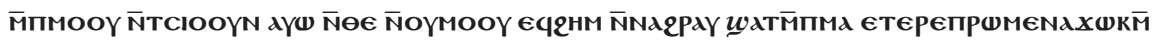

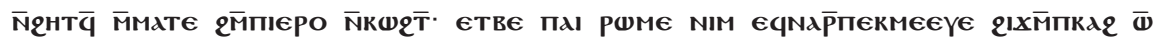

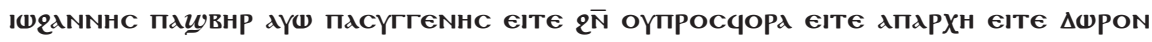

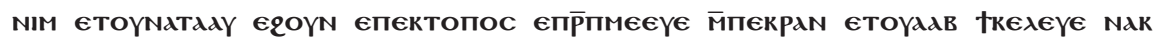

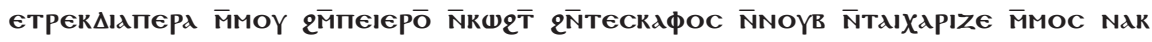

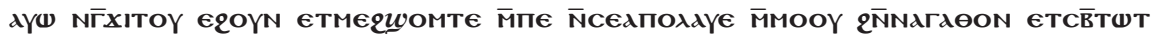

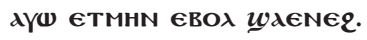


sie in den dritten Himmel eingenommen werden, den ich als Gabe meinem lieben Johannes gewährt habe, und sie werden die Güter erben, die sich darin ewiglich befinden.”31

The vision of the afterlife deploying in our text is actually a complex one and draws upon a multiplicity of sources: the motif of the river / lake of fire stems most probably from the Jewish, then Christian apocalyptic tradition, ${ }^{32}$ even if the influence of the Greek Pyriphlegethon, a blazing river both punishing and purifying, cannot be completely ruled out; ${ }^{33}$ the "golden boat" steered by John the Baptist echoes the "golden boat" manned by angels and ferrying Paul over the Acherousia lake into the city of Christ; ${ }^{34}$ the last baptism of the righteous finds its

31 Gloria Praecursoris 10 (BM Or. 7024, f. 15v-16r; 143 B.): пєхєாє тPOC on $\overline{\mathbf{M}} \overline{\mathbf{C}} \overline{\mathbf{H}} \overline{\boldsymbol{X}} \boldsymbol{x \in} \Pi \mathbf{\epsilon} \boldsymbol{x} \overline{\mathbf{C}}$

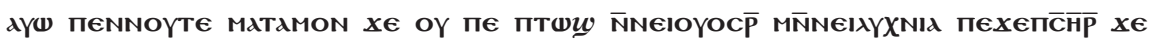

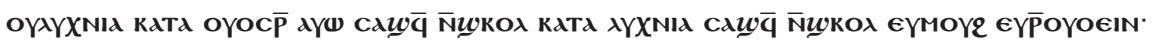

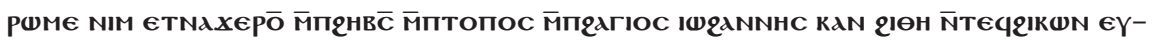

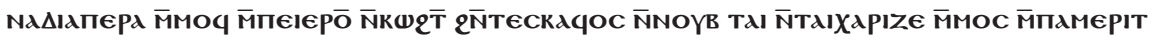

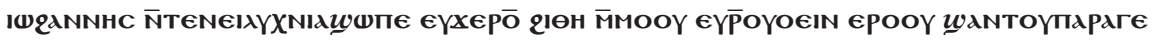

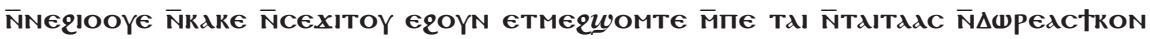

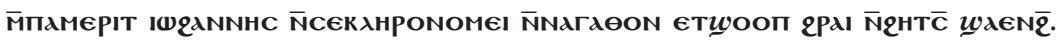

32 Cf. Dan 7,9-10; 2 Enoch 10,2 (ed. Mario Enrietti, "Libro dei Segreti di Enoc," in Apocrifi dell' Antico Testamento 2 [ed. Paolo Sacchi; Classici delle religioni 2,38; Torino: Utet, 1989], [479-594] 523,1-4 [there is no satisfying modern edition of this text]); 1 Cor 3,13-15; Clemens Alexandrinus, Excerpta ex Theodoto 38 (SC 23, 140,5-142,4 Sagnard); Testamentum Isaac 5,21-25 (ed. of the Coptic version Karl H. Kuhn, “The Sahidic Version of the Testament of Isaac," JThS N.S. 8 [1957]: [225-239] 234; trans. William F. Stinespring, “Testament of Isaac," in The Old Testament Pseudepigrapha 1: Apocalyptic Literature and Testaments [ed. James H. Charlesworth; Garden City, NY: Doubleday, 1983], [903-911] 909); Apocalypsis Pauli latina 32-36 (ed. Theodore Silverstein and Anthony Hilhorst, The Apocalypse of Paul: A New Critical Edition of the Three Long Latin Versions [Cahiers d'orientalisme 21; Genève: Cramer, 1997], 138,12-143,21).

33 Cf. Plato, Phaedo 114a-b; Lucianus, Philopseudeis 24,14-16 (ed. Vincenzo Longo, Lucianus: Dialogi 3 [Torino: Utet, 1993], [217-259] 242); Lucianus, Dialogi Mortuorum 6,1,5-6 (SCBO Luciani opera 4, 158,10-11 Macleod); Clemens Alexandrinus, Stromateis 5,14,91,1-2 (SC 278, 176,2-8 Le Boulluec). Cf. Oswald H. E. Burmester, “Egyptian Mythology in the Coptic Apocrypha," Orientalia 7 (1938): (355-367) 359-361, and Jan Zandee, Death as an Enemy According to Ancient Egyptian Conceptions (Leiden: Brill, 1960), 307-310. For further occurrences of the river of fire in Coptic literature, see Gabriele Giamberardini, La sorte dei defunti nella tradizione copta (Cairo: Edizioni del centro francescano di studi orientali cristiani, 1965), 95, 128-130, 180, 268.

34 Apocalypsis Pauli latina 23a (120,1-121,32 S./H.). Cf. the celestial boat in Apocalypsis Eliae 13,1-2 (ed. Georg Steindorff, Die Apokalypse des Elias: Eine unbekannte Apokalypse und Bruchstücke der Sophonias-Apokalypse: Koptische Texte, Übersetzung, Glossar [TU 17,3a; Leipzig: Hinrichs, 1899], 56). Cf. Burmester, "Egyptian Mythology" (see note 33), 363-364. The motif of navigation into the hereafter is documented on Coptic inscriptions as well: see texts and discussion in Giamberardini, La sorte dei defunti (see note 33), 61-63, 184-187, 192-194. 
counterpart in Apocalypsis Petri 14,$1 ;{ }^{35}$ Apocalypsis Pauli $22 \mathrm{~d} ;{ }^{36}$ Origen, Homilia in Lucam $24 ;{ }^{37}$ Resurrectio Jesu Christi $21,6,{ }^{38}$ whereas the hot water turning colder for the just has a parallel in Resurrectio Jesu Christi 21,$5 ;^{39}$ finally, the description of the fruitfulness of trees in the third heaven recalls the widespread millenarian expectations documented both in Jewish and Christian writings. ${ }^{40}$

No specifically Egyptian gods or demons appear, no evidently Egyptian or even just Egyptianizing names occur. We are left with the unprecedented-to my knowledge-focus on oars and lamps as object of knowledge. This probably offers us a glimpse of the Egyptian tradition of after death ferrying being assimilated within a Christian vision of the afterlife, amalgamating their different components into a unified and coherent whole. As a result, fitting Greek, Jewish, and Christian forms were extracted from their own cultural systems and integrated into Egyptian concepts, rather than being introduced as radical innovations, and vice versa..$^{41}$

35 Apocalypsis Petri 14,1 (ed. Paolo Marrassini, “L' Apocalisse di Pietro,” in Etiopia e oltre: Studi in onore di Lanfranco Ricci [ed. Yaqob Beyene et al.; Istituto Universitario Orientale, Dipartimento di studi e ricerche su Africa e paesi arabi, Studi Africanistici, Serie Etiopica 1; Naples: Istituto Universitario Orientale, 1994], [171-232] 230; trans. idem, “Apocalypse de Pierre," in Écrits apocryphes chrétiens 1 [see note 2], [745-774] 771).

36 Apocalypsis Pauli latina 22d (118,1-119,28 S./H.).

37 Origenes, Homilia in Lucam 24 (SC 87, 324-326 Crouzel/Fournier/Périchon).

38 Resurrectio Jesu Christi 21,6 (ed. Budge, Coptic Apocrypha [see note 2], 36; trans. Jean-Daniel Kaestli and Pierre Cherix, "Livre de la résurrection de Jésus-Christ par l'apôtre Barthélemy," in Écrits apocryphes chrétiens 1 [see note 2], [297-356] 348).

39 Resurrectio Jesu Christi 21,5 (35-36 B.; trans. 348 K./C.). On the Jewish origins of the notion of baptism by fire, see Carl-Martin Edsman, Le baptême de feu (Leipzig: Lorentz-Lundequistska Bokhandeln, 1940), 19-31. Edsman rightly argues that in the Apocalypse of Peter, the Apocalypse of Paul, and The Glory of the Precursor, the Acherusia lake and the lake of fire play the same role as water basins to be ferried over and / or to be baptized into, and are actually to be equated (ibid., 57-66 and 68-69). Furthermore, dealing with our text among other Coptic writings (ibid., 66-87), he views the "lake of fire" occurring in Book of the Dead 17, and other mentions of waters expected to be boiling up and burning dead in ancient Egyptian otherworld literature, as ideas which certainly influenced Coptic conceptions of the soul's destiny after physical death. However, he significantly concludes his survey stressing that the idea of a purification somehow connected with plunging into afterlife water basins is unattested in ancient Egypt (ibid., 72-73). 402 Baruch 29,5 (ed. Sven Dedering, Apocalypse of Baruch [The Old Testament in Syriac 4,3; Leiden: Brill 1973], 15); Papias in Irenaeus, Adversus haereses 5,33,3 (SC 153, 414,66-416,85 Rousseau/Doutreleau); Apocalypsis Pauli latina 22a (116,1-117,22 S./H.).

41 I take as theoretical starting point of the following analysis some insightful reflections by Adriana Destro and Mauro Pesce, La morte di Gesù: Indagine su un mistero (Milan: Rizzoli, 2014), 315 (note 45), on Jesus' followers explaining their leader's death on the textual basis of Jewish scriptures and interpreting Jewish sacred writings in the light of his crucifixion: "da un sistema culturale basato su scritture stabilizzate, si possono prelevare concetti e narrazioni che vengono poi ricomposti in un altro sistema. Il primo permane, il secondo si affianca ad esso e si specializza 
Notwithstanding the chronological distance, Budge derived indeed the interest in oars and lamps from the influence of two chapters of the Book of the Dead, namely, chapter 98 and chapter 99 A-B. ${ }^{42}$ Although in principle opposing Budge's "Egyptomania," even Oswald Burmester concluded confidently:

That the writer of the Encomium in question borrowed his description of the ferryman and the lamps in the oars of the ferry-boat directly from any illustration of the above mentioned passages in the Book of the Dead is out of the question, but, as Dr. Alexander Piankoff has suggested to me, he may have been acquainted with some popular tale of the ferryman Her-f-haf and of the luminous Eye of Rē in the boat in which he traversed the regions of darkness, that still survived among the Christian Egyptians of his day. ${ }^{43}$

He then goes as far as to refer to a late Ethiopic version of the Demotic story of Setne Khaemwaset, as well as to demonstrate the ancient Egyptian origin of further otherworldly characters featuring in Coptic literature. ${ }^{44}$

These useful remarks by Burmester, in my view, point to the way to get out of the dilemma. After a preliminary survey, which is still underway, I have been able to find some other interesting parallels in more recent Egyptian funerary texts: ${ }^{45}$

per singoli punti. Oppure, nel secondo sistema, si aggiungono o si intrecciano componenti non rintracciabili nel primo perché alcuni fattori sono estrapolati e/o sottratti alla logica sistemica.” The first cultural system is obviously in our case the Egyptian one, or, more to the point, a huge section thereof, i.e., funerary religion.

42 Budge, Coptic Apocrypha (see note 2), lxx-lxxii. According to Martin A. Stadler, "Funerary Religion: The Final Phase of an Egyptian Tradition," in The Oxford Handbook of Roman Egypt (ed. Christina Riggs; Oxford: Oxford University Press, 2012), 383-397, we can follow the transmission of Egyptian funerary texts until about 250 C. E. After the middle of the 3d century C. E., they disappear from mummy labels, coffins, and papyri (ibid., 386 and 393). On their part, chapters of the Book of the Dead were excerpted and copied until the 1st century C.E. at the latest, as parts of Book of the Dead 17 were included in the so-called Book of Ba from Akhmim (ibid., 387-388). We know however of Egyptian mortuary guilds (nekrotaphoi) still active in the 5th century C. E.: Frankfurter, Religion in Roman Egypt (see note 17), 72-73, surmises that "later it would be such guilds or the craftspeople associated with them who would maintain through Christianization traditional iconography on grave stelae, terminology and beliefs in epitaphs, and rituals in mummification."

43 Burmester, "Egyptian Mythology" (see note 33), 359-364 (quotation: 364).

44 Burmester, "Egyptian Mythology” (see note 33), 364-367. See also Zandee, Death as an Enemy (see note 33), 310-319, 329-330, 333-335, 337, and Heike Behlmer-Loprieno, "Zu einigen koptischen Dämonen," Göttinger Miszellen 82 (1984): (7-23) 15-18.

45 I owe all my knowledge of this literature to the ample selection of texts, provided with English translation, introduction, and notes, by Mark Smith, Traversing Eternity: Texts for the Afterlife from Ptolemaic and Roman Egypt (Oxford: Oxford University Press, 2009). I quote passages and comments from this work. 
The Book of Glorifying the Spirit 4-5 says: "Osiris foremost of the Westerners will ferry across in this ferry boat of the flame of the pool. When he has landed at the field of offerings, bread and beer will be given to him there... The twin boats will be made double for you, when they are joined together. The ways of darkness will be illuminated for you"; in 5-10, protection from flames and every burning and scorching thing is assured to the deceased, for "he has poured out water for your corpse. He has celebrated a festival in your name. He has made invocation offerings to you daily." ${ }^{46}$ In the Spell for Striking the Copper, ${ }^{47}$ torches are lit in order to protect the deceased for whom they are lit, as well as to illuminate and purify his road in the darkness, thus enabling his movements. All of that, because they stand for the eye of the solar deity. Interestingly enough, the word road (w3.t) is sportively written as wi3, that is, "solar boat," which brings us back right to the cultural imagination voiced in the passages from the Book of Glorifying the Spirit excerpted above. ${ }^{48}$

In the light of these passages, and contrary to Alexander Piankoff and Burmester, I would not dare to speak of the survival down to Late Antiquity of a popular tale of the ferryman and the Eye of Re. Taking as a starting point the common reference to dark paths to be ferried over and to lamps / torches to be lit in order to illuminate them, I would rather argue for resilient socio-cultural presuppositions on how to make it to and through the afterlife: ritual offerings performed by the living at the sanctuary and her / his righteousness as proven by meeting three moral and social requirements (feeding the hungry; giving the thirsty something to drink; dressing the naked) are supposed to grant her / him after death the right to have at her / his disposal a boat to board, a pilot, and sources of lights, in order to head safely across darkness into paradisiacal bliss, the latter being conceived and described as perennial overabundance of earthly goods. ${ }^{49}$ The narrative and

46 Book of Gloryfying the Spirit 4-5.10 (Papyrus Şekowski col. X+4 [Roman period]; trans. Smith, Traversing Eternity [see note 45], 177).

47 Spell for Striking the Copper (trans. Smith, Traversing Eternity [see note 45], 393-394).

48 Smith, Traversing Eternity (see note 45), 392-394.

49 A Ramesside funerary inscription quoted by Jan Assmann, Tod und Jenseits im alten Ägypten (2d ed.; München: Beck, 2010), 400, well exemplifies the connection between meeting the three aforementioned requirements and crossing into the Elysium on a boat: "Fahr über, große Fähre des Westens. / Fahre in Frieden über zum Westen! Ich gab Brot dem Hungrigen, / Wasser dem Dürstenden, / Kleider dem Nackten.” On feeding, giving something to drink, and dressing as means to inherit the kingdom, cf. however Matt 25:34-40, and its reception in the homilies De Paenitentia (ed. Ernest A. W. Budge, Coptic Homilies Edited from the Papyrus Codex Oriental 5001 in the British Museum [London: Printed by Order of the Trustees, 1910], [66-79] 77-78; trans. Orlandi, Omelie copte [see note 26], 24), circulating under the name of Theophilus of Alexandria (perhaps authentic: 4th-5th century C.E.), and De Baptismo (Pierpont Morgan Library M 611, p. 32; trans. Orlandi, Omelie copte [see note 26], 40), attributed to Peter of Alexandria (second half of the 7th century C.E.). On corn and water offerings-libations?-to John the Baptist, see Theodosius of Alexandria (?), De Baptismo (CSCO 268, 65,8-20 Kuhn; trans. Orlandi, Omelie copte [see note 26], 22,1-2; 6th or 8th century C. E.). 
literary structuring of this discourse attracts, combines, and binds together the single specific motifs we have detected and isolated as originating with Jewish and Christian texts.

Such a coexistence and interpenetration of Greek, Jewish, Christian, and Egyptian traditions, as well as their transposal into a Christian discourse on the afterlife, have left traces both in archaeological documentation ${ }^{50}$ and in written traditions. ${ }^{51}$

50 A brief but accurate survey of the evidence can be read in Françoise Dunand and Christiane Zivie-Coche, Gods and Men in Egypt: 3000 BCE to 395 CE (trans. David Lorton; Ithaca, NY: Cornell University Press, 2004; trans. of Dieux et hommes en Égypte: 3000 av. J.-C. - 395 apr. J.-C. [Paris: Colin, 2002]), 333-338. See also Martin Krause, "Das Weiterleben ägyptischer Vorstellungen und Bräuche im koptischen Totenwesen," in Das römisch-byzantinische Ägypten: Akten des internationalen Symposions 26.-30. September 1978 in Trier (ed. Günter Grimm, Heinz Heinen, and Erich Winter; Mainz: Zabern, 1983), 87-92. On parallels with the ancient Egyptian Books of the Dead embedded in so-called Gnostic writings, see Frankfurter, Religion in Roman Egypt (see note 17), 257-264, and Nicola Denzey Lewis, "Death on the Nile: Egyptian Codices, Gnosticism, and Early Christian Books of the Dead," in Practicing Gnosis: Ritual, Magic, Theurgy and Liturgy in Nag Hammadi, Manichaean and Other Ancient Literature, Essays in Honor of Birger Pearson (ed. April D. DeConick, Gregory Shaw, and John D. Turner; Leiden: Brill, 2013), 161-180. The related praxis of burying books inside the grave (e.g. Psalms; Gospel of Peter; Apocalypse of Peter) or putting inscribed wrappings on the dead (reporting, for example, Gospel of Thomas 5) seems to have persisted until the 10th century C. E.: see more specifically Annemarie Luijendijk, "Jesus says: 'There Is Nothing Buried That Will Not Be Raised': A Late-Antique Shroud with Gospel of Thomas Logion 5 in Context," ZAC 15 (2011): 389-410. On Coptic tomb decoration as $\varphi v \lambda \alpha \kappa \tau$ prov in 12th century C. E. Middle Egypt, and its dependence on ancient Egyptian models, while reproducing and describing on walls excerpts from homiletic texts, see Jacques van der Vliet, "Literature, Liturgy, Magic: A Dynamic Continuum," in Christianity in Egypt: Literary Production and Intellectual Trends, Studies in Honor of Tito Orlandi (ed. Paola Buzi and Alberto Camplani; Studia Epheremidis Augustinianum 125; Rome: Institutum Patristicum Augustinianum, 2011), 555-574. 51 Papyrus Lange 11-13; 16-17; 19-20; 36-38 (7th century C. E.) (ed. Hans O. Lange, "Ein faijumischer Beschwörungstext," in Studies Presented to F. Ll. Griffith [ed. Stephen R. K. Glanville; London: Egyptian Exploration Society, 1932], 161-166; trans. Marvin W. Meyer, Ancient Christian Magic: Coptic Texts of Ritual Power [ed. Marvin W. Meyer and Richard Smith; Princeton: Princeton University Press, 1999], 238): "Yea, shake yourself today with your power, Petbe, who is in the abyss ... Horasias Phankapre ..., whose head is fixed in heaven, whose feet are fixed on the earth ... I invoke you, who lifts up the two cherubim of light, Marioth, Gabriel, Amuath, the sun of the underworld"; similarly, in Papyrus Milano Vogliano copto [Università Statale di Milano, Vogliano copto] 16 (5th century C. E.), text C II, following mentions of Osiris, Isis, the Hapis bull and Seth, Petbe "in the form of a bull" is referred to as "the one who overturns the foundations of the earth": "move, rise! ... if you move, the foundations of the earth are confused, if you move, the supports of the sky are confused" (P. Milano Vogliano copto, text C II, lines 5-7; 9-12 [ed. Sergio Pernigotti, “Il codice copto," Studi Classici e Orientali 29 (1979): (19-53) 33-34]). Formulas describing primeval gods as underground / underworld serpents, rising and moving, and thereby shaking the earth, are here echoed almost verbatim: cf. PM $\mathrm{II}^{2}$ 462,10c-e (trans. 
Therefore, mutatis mutandis, we can roughly reassert the conclusions which Martin Stadler has drawn from his discussion of the main literary and archeological sources on Egyptian funerary religion in Roman times: "The evidence suggests a persistence of traditional beliefs concerning the afterlife rather than their alteration ... new forms of equipment, tomb decoration, and types of text accompanying the dead cannot be denied, but the conceptual foundations might be the same." 52

The following could be reasonably counted as one of the most representative cases of such persistence to be found in literary sources, while surely being the most interesting one for our study:

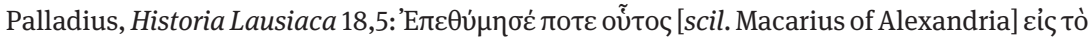

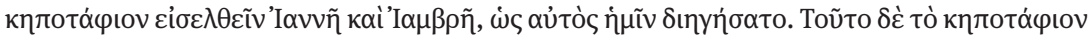

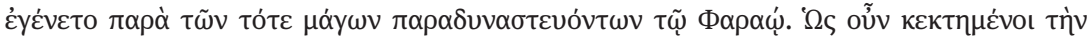

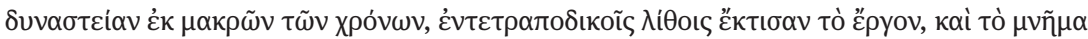

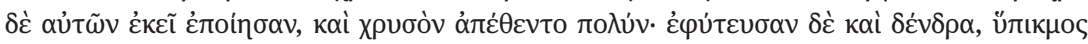
yó

137-138 K.): "that god (scil. Kematef) who emerged into being before the sun-disk . . . whenever he rises, the earth quakes"; Urk. VIII 138b (110; trans. 138 [note 796] K.): "whenever he (scil. Amun-Kematef) shakes, everything trembles ... all lands quake for him when he moves"; also said of Osiris in a Ramesside hymn quoted in Klotz, Caesar in the City of Amun (see note 11), 138 note 796 ("if you move around, the earth quakes"). An associate or alter-ego of Iao, Petbe is represented as falcon-shaped and serpent-headed like the latter (cf. P. Milano Vogliano copto 16, text C III, line 2 [33-34 P.] and London, Oriental Manuscript 5987, lines 88-91 [ed. Angelicus Kropp, Ausgewählte koptische Zaubertexte 1 (Brussels: Édition de la Fondation égyptologique reine Élisabeth, 1931), 25]), or as extending his head up to the sky and his foot down into the Abyss, his back resembling the form of a snake (Papyrus Michigan 4932, recto, lines 12-15 [ed. William H. Worrell, “Coptic Magical and Medical Texts,” Orientalia 4 (1935): (1-37; 184-194), 185]). He thus comes close to depictions of Kematef-Kmeph as an enormous falcon-headed snake or falcon-shaped snake, as we find in PM II ${ }^{2}$ 462,10c-f, and Philo of Byblos, Fragmenta 9,29-50 (ed. Karl Müller and Theodor Müller, Fragmenta Historicorum Graecorum 3 [Paris: Firmin-Didot, 1928], 572-573). His huge size, as described in Papyrus Michigan 4932, is paralleled in traditions on the gigantic size of the Egyptian cosmic god. For the formula "my / whose head is the sky, my / whose feet are the earth / netherworld," see Jan Assmann, Sonnenhymnen in thebanischen Gräbern 1 (Mainz am Rhein: Zabern, 1983), 125, text no. 88, lines 14-15; Papyri Graecae magicae XII,242; XIII,767; XXI,4 (ed. Karl Preisendanz, Papyri Graecae magicae: Die griechischen Zauberpapyri 2 [2d ed.; Sammlung Wissenschaftlicher Commentare; Stuttgart: Teubner, 1974], 74,31; 122,20; 146,4); Macrobius, Saturnalia 1,20,17 [BSGRT, 115,12-15 Willis], on Sarapis. On Coptic demons at the crossroads of Jewish as well as Christian apocryphal literature, and Egyptian traditions, see Behlmer-Loprieno, “Zu einigen koptischen Dämonen” (see note 44), 15-18.

52 Stadler, "Funerary Religion" (see note 42), 391; italics D. T.

53 Palladius, Historia Lausiaca 18,5 (ed. Gerhardus J. M. Bartelink, La storia Lausiaca [Scrittori Greci et Latini; Verona: Fondazione Lorenzo Valla, 1974], 80,39-46). 


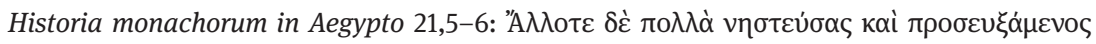

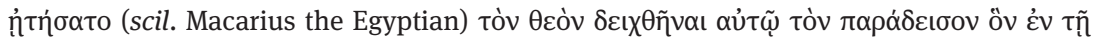

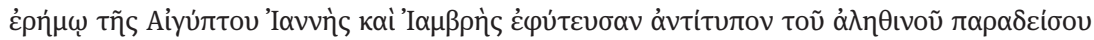

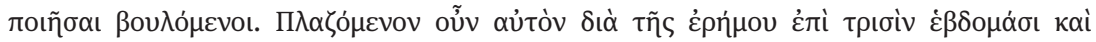

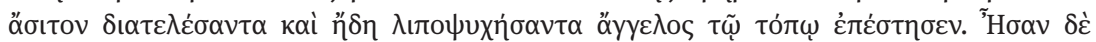

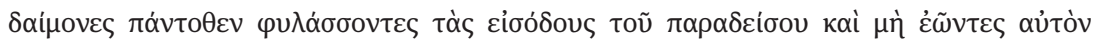

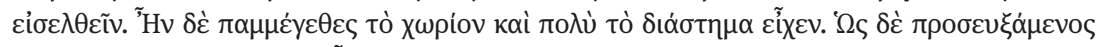

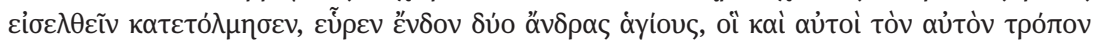

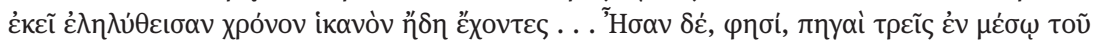

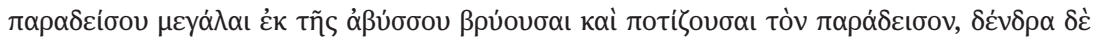

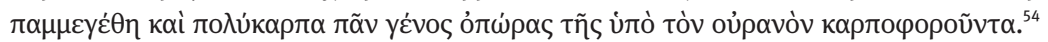

The term кплото́ $\varphi$ เо occurs only four times in chapter 18 of Palladius' Historia Lausiaca ${ }^{55}$ in the whole corpus of Greek literature. As the description of the building makes clear, the term refers to the typically Egyptian garden tombs. ${ }^{56}$ Read together, then, the two parallel passages show how firmly and deeply such constructions still marked both the Egyptian landscape and cultural imagination down to the 5th century C. E., as earthly places of paradisiacal bliss and never ending fulfillment, where the $3 h$ s, that is, the glorified spirits of the ancestors (here labeled as "demons," which matches perfectly with the corresponding use of the Coptic cognate $1 \mathrm{~b} / \mathrm{\imath}$ ), dwell and live close to the gods forever, being provided with everything they need..$^{57}$ The two Christian texts are actually ambiguous in

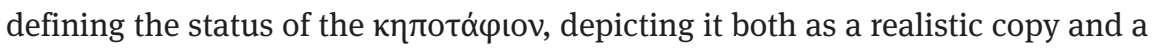
demoniac counterfeit of the garden of Eden, set up by virtue of Egyptian magic. ${ }^{58}$ Such ambiguity shows that Egyptian ideas on garden tombs and the deceased

\section{Historia monachorum in Aegypto 21,5-6 (125,25-33 F.).}

55 Palladius, Historia Lausiaca 18,5,1.3; 18,6,8; 18,7,6 (80,39.41; 82,53.59 B.).

56 Cf. Ägyptische Urkunden aus den Königlichen Museen zu Berlin: Griechische Urkunden 4 (1912): 1120 (Alexandria, November 24th, 5 B. C. E.); Emil Seckel and Wilhelm Schubart, Der Gnomon des Idios Logos 1: Text (Ägyptische Urkunden aus den Staatlichen Museen zu Berlin: Griechische Urkunden 5,1; Berlin: Weidmann, 1919), 1510,11-16 (Theadelphia, around 150 C. E.).

57 On garden tombs and visiting spirits in the Egyptian worldview, see Assmann, Tod und Jenseits (see note 49), 302-317. On tombs as temples, as well as on temples of Graeco-Roman times as divine burials, sacred spaces and lake-provided gardens of fullness intended to provision the dead up to their fill with everything they want and need, cf., for example, the Book of Traversing Eternity (Papyrus Leiden, National Museum of Antiquities T 32; first half of the 1st century C. E.). On stone monumental and temple tombs until the $3 \mathrm{~d}$ century C. E., see Marjorie S. Venit, "Alexandria," in Riggs, The Oxford Handbook of Roman Egypt (see note 42), (103-121) 116-118, and Katja Lembke, "City of the Dead: Tuna el-Gebel," in Riggs, The Oxford Handbook of Roman Egypt (see note 42), (205-222) 210-216.

58 Eva Schulz-Flügel, “AMATOR EREMI: Zum Stellenwert des Begriffs 'Wüste’ im ägyptischen und europäischen Mönchtum,” in Christliches Ägypten in der spätantiken Zeit (ed. Dmitrij Bumazhnov; Tübingen: Mohr Siebeck, 2013), (217-230) 224-225. 
occupying or visiting them, and Christian expectations and images of Paradise evidently competed but at the same time tended to merge. ${ }^{59}$

In the second half of 1st century B. C. E. Diodorus Siculus' Egyptian informants had already identified marshes and blooming fields next to Memphis with Homer's

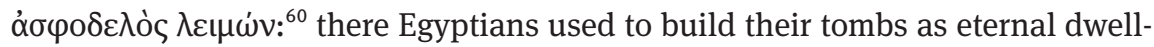
ings for the deceased, the latter landing in such fields after being ferried over the Nile and the "Acherusian lake" on a boat steered by a pilot. ${ }^{61}$ An Egyptian text has confirmed the overall reliability of Diodorus' report, documenting, "dass es in der Nähe von Memphis ein Gelände mit Wasserläufen und Gärten gab, das den ägyptischen Namen sh.t j3r.w trug, 'das Binsengefilde,' die ägyptische Bezeichnung des Elysiums als eines Ortes, an dem die seligen Toten sich ewigen Glücks, Friedens und ewiger Fülle erfreuten.”62

Therefore, it cannot be far wrong to claim that Diodorus' report provides one more instance of the persisting symbolic power demonstrated by the image of the garden tomb. Even more important for our analysis: the spectrum of topoi here deployed (lake to be crossed; ferry-boat and ferry-man taking the dead to their final destination; bliss enjoying a material paradise) basically matches with the set of motifs we have identified in The Glory of the Precursor. The same form of Egyptian discourse about successfully crossing to a hoped-for afterlife is here applied to substantiate and make sense of the Greek underworld, at the same time translating the Egyptian worldview into the Greek idiom. ${ }^{63}$

59 Cf., for example, the spirits / demons guarding the entrances to "Paradise" in Historia monachorum in Aegypto 21,6 (125,30-32 F.) with the Cherubs guarding the way to the garden of Eden in Gen 3,24. On early Egyptian monastic culture as reflecting not just a radical shift from temple to monastery and thus giving reason to believe that "monks with traditional priestly backgrounds" continued "to articulate their traditional literary and ritual sensibilities in the new idiom," see Frankfurter, Religion in Roman Egypt (see note 17), 204-217 and 238-264 (quotation: 263).

60 Cf. Homerus, Odyssea 24,13.

61 Diodorus Siculus, Bibliotheca historica 1,96,6-8 (BSGRT, 162,8-163,16 Vogel). Some useful remarks on Diodorus' passage are found in Merkelbach, Isis Regina (see note 19), 232-233. Assmann, Tod und Jenseits (see note 49), 400-405 and 434-440, analyzes the cluster of ideas revolving around crossing river and water basins by boat and landing into "paradise" as "sakramentale Ausdeutung" of the actual phases of the funerary ritual climaxing in the procession from the house to the burial place, the enlivening of the mummy, and the food offerings and water libations made at the tomb after the mummy was buried.

62 Assmann, Tod und Jenseits (see note 49), 317.

63 Cf. the juxtaposition of Egyptian and Greek images and formulas in the inscription of Apollos from Lycopolis (1st-2d century C. E.): the deceased proclaims "qu'il est devenu un 'serviteur du siège d'Osiris abydénien', ce qui est conforme à la vision égyptienne du sort des 'justifiés', mais en même temps qu'il a été conduit dans la 'plaine élyséenne des bienheureux' par 'Hermès Cyllénien' et qu'il n’a pas bu 'l'eau du Léthé': vision typiquement grecque du séjour des morts. Or, 
All in all, then, continuity and synthesis of Egyptian traditions were apparently allowed into the world of The Glory of the Precursor, whether by means of "the trade in ritual ('magical') spells, by which priestly materials continually entered popular culture and application," due to "a matrix of shared perspectives, as it were, among those who wrote for Egyptian audiences," or thanks to "an Egyptian 'mentality' that tended to imagine 'post mortem' dynamics and forces within a limited, traditional range of symbols and motifs." The "singular result" of the convergence of Egyptian and Greek logoi-and we may confidently add, for our author: Jewish and Christian-on the afterlife "posed a convenient reflection of, and therefore source for, the image" of the deceased crossing on a boat through darkness into paradise, transmitted by the encomium to John the Baptist. ${ }^{64}$

parallèlement, le relief qui occupe la partie supérieure de la stèle représente le défunt en costume égyptien, conduit par Anubis en présence d'Osiris. Ici la symbolique est double; l'idéologie funéraire joue manifestement sur deux registres: la plaine des bienheureux peut être assimilée au 'Champ des Roseaux' égyptien, tandis qu'Anubis est l'équivalent de l'Hermès conducteur des morts" (Françoise Dunand and Roger Lichtenberg, "Pratiques et croyances funéraires en Egypte romaine,” ANRW 2,18,5 [Berlin: de Gruyter, 1995]: [3216-3315] 3304-3305). For more instances of Egyptian architectural and iconographic features combined with Greek and Roman formal spaces and decorative motifs in tombs of the Roman period, and thus engendering bilingual readings, see also Dunand and Zivie-Coche, Gods and Men (see note 50), 319-325; Venit, "Alexandria” (see note 57), 116-118; Lembke, "City of the Dead" (see note 57), 216-219. Moving from iconography and architecture to ritual praxis, it is worth noting that the custom of placing a coin next to the deceased as payment for the underworld ferryman was widespread in Graeco-Roman Egypt, given its compatibility with the Egyptian traditional vision of the hereafter (Dunand and Lichtenberg, "Pratiques et croyances funéraires" [see above], 3302-3303).

64 I paraphrase here the fine reflections of David Frankfurter, Elijah in Upper Egypt: The Apocalypse of Elijah and Early Egyptian Christianity (Studies in Antiquity \& Christianity; Minneapolis: Fortress, 1993), 233. Cf. also Heike Behlmer, "Ancient Egyptian Survivals in Coptic Literature: an Overview," in Ancient Egyptian Literature: History and Forms (ed. Antonio Loprieno; Leiden: Brill, 1996), (567-590) 584: "at the time orthodoxy was established, from the second half of the fourth century onwards, however, the Egyptian tradition had already become part of Hellenistic-and Christian-culture, had transformed it and had been even more transformed by it.” 


\section{Explaining Potentials: Concluding Remarks}

Having surveyed two test-cases of alleged ancient Egyptian survivals in Coptic texts, we are now in a better position to evaluate the actual explanatory potential of the supposed influences, as well as to arrive at some preliminary conclusions.

The Mysteries of John offered us the possibility to identify exact correspondences and to trace them directly back to ancient Egyptian traditions and conceptions. The latter, in turn, enabled us to clarify and account for the occurrence of an apparently strange, isolated and unexplained detail in the heavenly topography of the Nile's sources, such relocation of its origin by contrast being quite customary in antiquity. ${ }^{65}$

The Glory of the Precursor had no such solid ground to offer, and the investigation had to rest on much more uncertain premises allowing for a merely thematic comparison. This comparison led us to speculate on the historical continuity and enduring symbolic power of a discourse on afterlife travels and routes harmonizing over time Egyptian, Greek, Jewish, and Christian materials. Such discourse might well explain the co-existence and interpenetration in our encomium of elements stemming from Jewish and Christian literature and others that are Egyptian in flavor, yet, still unparalleled as such in Egyptian texts. Probably, and even more importantly, the comparison reminded us that, in the attempt to identify and isolate specific traditions as sources for images occurring in a text, we are never dealing with "fragments but rather amalgams, difficult to analyze. And probably we should not even insist on separating neatly what testifies to interconnections." ${ }^{\circ 6}$

If there is any common conclusion to be drawn from the analysis of both texts, we may reassert that the transfer of knowledge is not a matter of simply reconstructing literary interrelationships among texts or speculating on theoretically more or less vague traditionsgeschichtliche Beziehungen. As texts themselves are to be understood as complex cultural artifacts, and changing idioms and legends do not live their textual existences apart from the cultural and social context within which they are being developed, the whole of a culture in all its forms, practices, and products is involved in such a remembering and self-defining process over time between reassertion and innovation. All these forms, practices, and products should therefore be accorded a place in our analyses.

65 Homerus, Odyssea 4,475.579; Parmeno of Byzantium 604A (288,1 L./N.); Philo, De fuga et inventione 179-180 (ed. Paul Wendland, Philonis Opera 3 [Berlin: Reimer, 1898], 149,15-23), and De vita Mosis 2,195 (ed. Leopold Cohn, Philonis Opera 4 [Berlin: Reimer, 1913], 245,18-22); Heliodorus, Aethiopica 9,9,3 (ed. Robert M. Rattenbury and Thomas W. Lumb, Héliodore: Les Éthiopiques 3 [Paris: Belles Lettres, 1960], 51,7-12); Porphyrius, Fragmentum 360F (BSGRT, 431,40-41 Smith). 66 Walter Burkert, Babylon, Memphis, Persepolis: Eastern Contexts of Greek Culture (Cambridge: Harvard University Press, 2007), 123. 